Relations industrielles

Industrial Relations

\title{
Bélanger, Yves et Robert Comeau, sous la direction de, La CSN : 75 ans d'action syndicale et sociale
}

\section{Gilles Ferland}

Volume 55, numéro 3, 2000

URI : https://id.erudit.org/iderudit/051340ar

DOI : https://doi.org/10.7202/051340ar

Aller au sommaire du numéro

Éditeur(s)

Département des relations industrielles de l'Université Laval

ISSN

0034-379X (imprimé)

1703-8138 (numérique)

Découvrir la revue

Citer ce compte rendu

Ferland, G. (2000). Compte rendu de [Bélanger, Yves et Robert Comeau, sous la direction de, La CSN : 75 ans d'action syndicale et sociale]. Relations industrielles / Industrial Relations, 55(3), 547-549. https://doi.org/10.7202/051340ar

Tous droits réservés @ C Département des relations industrielles de l'Universite Laval, 2000
Ce document est protégé par la loi sur le droit d'auteur. L’utilisation des services d'Érudit (y compris la reproduction) est assujettie à sa politique d'utilisation que vous pouvez consulter en ligne.

https://apropos.erudit.org/fr/usagers/politique-dutilisation/ 
theoretical focus. The one concept that is (somewhat mechanically) used to links all the essays - the 'double shift', referring to the process whereby, since 1980, '[s]imultaneously, decisions most important to unions moved away from the national arenas "upward" towards transnational arenas and "downward" towards subnational ones, transferring matters from arenas where unions could be effective towards those where they were weaker' - is itself descriptive rather than explanatory. A brief survey of the limits of various 'schools' of analysis (industrial relations, political economy, etc.) is offered by Martin and Ross in an introductory essay but the treatment of each is cursory and nothing is put in their place, except the need to "work at a lower level of abstraction to study the choices of a limited number of actors at a given time'. The justification for this is that 'the world of unions is not easily reducible to parsimonious analysis' (p. 4-8).

To which the answers must be: what is? and who ever said it was easy to theorize and strategize? Moreover, even the best empiricist needs a theory and usually has an unelaborated one lurking around somewhere. As far as I can tell the one lurking in most, although not all, of the essays here, is that of Marxist class analysis, even though, in their introductory essay, Martin and Ross ostensibly dismiss this approach: 'Marxists see unions as organised intermediaries between the "working class" and capitalists whose performance is measured by the degree to which they promote "class interests"... Marxists are thus troublesome because they tend to be reductionist, looking not at what unions do but how closely they approximate the pursuit of "class interests" assumed a priori' (p. 5). Yet, despite the scare quotes and the derision, every essay in this volume - and especially best ones by Howell, Mahon and Martin and Ross themselves - is clearly operating on the basis of a notion of working class interest, conceived not only in terms of the weakening of labour vis-à-vis capital being something bad for working people, but even in terms of some notion of liberating workers from the logic of capitalist domination and competition being a good thing. It is unfortunate indeed that we have come to live in an academic climate today when those scholars who have the most experience, talent and resources to observe European working classes most closely and perceptively do so without contributing to developing and improving the very Marxist theory and strategy whose foundational ideas and ideals still implicitly motivate and guide their studies.

Leo Panitch York University

\section{La CSN : 75 ans d'action syndicale et sociale}

sous la direction d'Yves Bélanger et Robert Comeau, Sainte-Foy : Presses

de l'Université du Québec, 1998, 339 p., ISBN 2-7605-0965-6.

Cet ouvrage est composé de textes issus d'un colloque tenu à l'Université du Québec à Montréal, au printemps 1997, à l'occasion du $75^{\circ}$ anniversaire de la Confédération des syndicats nationaux (CSN).

Les actes de ce colloque sont divisés en quatre parties. Les deux premières parties de l'ouvrage sont essentiellement consacrées à l'histoire de la CSN. Les deux autres parties du livre font état des orientations actuelles de la Centrale ainsi que des nouvelles avenues qui s'ouvrent au syndicalisme.

La première partie historique du volume porte sur la CSN et l'évolution du mouvement ouvrier au Québec. Les thèmes abordés traitent des origines de la centrale syndicale (CTCC) et de son évolution jusqu'à la Deuxième Guerre 
mondiale, des politiques et des actions de la Centrale au regard de la protection de la langue française de 1921 à 1996 , de l'avènement du syndicalisme de combat dans les années 1960 , de l'importance de la revendication syndicale dans les années 1970 , du radicalisme des années 1975 à 1985 et de la recherche d'un nouveau contrat social depuis 1985.

Dans la deuxième partie historique de l'ouvrage, laquelle est consacrée à l'apport de la CSN à la vie syndicale, sont traitées des questions aussi diverses que la CSN et les médias, les préoccupations de la Centrale en matière de condition féminine, plus particulièrement en ce qui concerne l'équité salariale, la CSN et la promotion des droits de la personne, le rôle des conseils centraux, la position de la CSN par rapport à la loi, l'approche récente de la Centrale en matière de relations du travail ainsi que les rapports que cette organisation entretient avec les autres groupes syndicaux.

La troisième partie du volume, intitulée «Quel syndicalisme pour aujourd'hui ? ", comprend un essai de synthèse sur l'action politique de la $\mathrm{CSN}$, des textes sur les stratégies nouvelles de la centrale face à l'exclusion, sur les stratégies pour l'emploi et sur le passage du syndicalisme de combat au partenariat social. Des écrits sont également consacrés au projet de société de la CSN, aux stratégies de la Centrale sur la modernisation des entreprises et au bilan des expériences de participation de la part de certains syndicats locaux de la CSN.

La quatrième partie des actes du colloque porte sur les enjeux actuels du syndicalisme et sur les orientations de la CSN à l'égard de ces enjeux. Après la présentation d'un texte sur les syndicats européens face aux nouveaux défis structuraux de la mondialisation, les sujets développés portent sur les besoins de mobilisation face à la nouvelle économie, sur les réponses de la CSN aux besoins des jeunes travailleurs, sur les revendications des femmes dans le secteur public et parapublic, sur les adaptations et les innovations qui s'imposent aux organisations syndicales devant les changements de société. L'ouvrage se termine par un texte du président de la Centrale qui présente quels sont, à son avis, les défis de l'heure à la CSN tant sur les plans syndicaux que sociaux.

L'ouvrage est un collectif auquel ont participé trente-six collaborateurs et collaboratrices : des professeurs et des chercheurs, des journalistes, des militants de la CSN, actuels ou anciens, élus ou salariés. Comme il arrive souvent dans ce genre d'ouvrage collectif, les textes colligés ne sont pas tous de même qualité et l'ensemble comporte des redites. En l'espèce, le volume contient des textes qui sont franchement anecdotiques et d'autres, plutôt hagiographiques. Il y a aussi plusieurs répétitions, en particulier dans les textes qui portent sur l'histoire de la CSN jusqu'aux années 1970. En revanche, l'ouvrage contient des exposés, surtout ceux qui ont été écrits par des professeurs et chercheurs, dont la qualité est remarquable et qui méritent d'être lus. Nous nous référons particulièrement aux textes suivants : « La CSN et le syndicalisme de combat »; «L'action syndicale et l'importance de la revendication » ; "La CSN de 1975 à aujourd'hui » ; «La CSN et les autres groupes syndicaux» ; «De l'apolitisme à la souveraineté » ; «Le mouvement syndical et les enjeux économiques »; « Du combat au partenariat»; « La CSN et la démocratie au travail »; « Nouvelle société, nouveau syndicalisme ?».

Les objectifs poursuivis par les organisateurs de ce colloque consistaient, si l'on se fie à l'avant-propos du livre, à faire un survol de l'histoire de la CSN et à débattre des orientations actuelles de la Centrale. Bien que le fil conducteur de l'ensemble de l'ouvrage ne soit pas toujours évident, on peut certes conclure que dans l'ensemble, les objectifs recherchés par les organisateurs sont 
atteints. De façon plus particulière, pour reprendre les propos de Gérald Larose, ci-devant président de la CSN, les actes de ce colloque permettent de découvrir que la CSN a toujours été un mouvement, lequel s'est déplacé sur les plans idéologique, politique, géographique au fil des ans, et lequel a épousé le chemin parcouru par le peuple québécois. Les textes reflètent également les débats qui ont cours actuellement dans la Centrale (et dans les autres organisations syndicales), en particulier sur les grands enjeux stratégiques des années 2000 et sur les orientations à donner à l'action syndicale.
En somme, l'ouvrage, malgré les lacunes inhérentes à ce genre, peut être utile à tous ceux - professeurs, chercheurs, étudiants, militants, intellectuels - qui s'intéressent à l'histoire de l'un des courants du mouvement syndical québécois, voire même à l'histoire du Québec et surtout, peut-être, à l'histoire de l'évolution des processus de démocratisation des sociétés.

Gilles Ferland Sainte-Mélanie, Québec

\section{Patrick Lenihan: From Irish Rebel to Founder of Canadian Public Sector Unionism \\ edited by Gil Levine, St. John's, Newfoundland: Canadian Committee on Labour History, 1998, 203 p., ISBN 1-894000-00-5.}

At a time when the Canadian labour movement seems intent on splitting into quarrelling jurisdictional factions, it is ironic to read of a man who spent a large part of his life trying to unite workers into a cohesive labour movement representing the interests of workers in both the public and private sectors. But that's what Patrick Lenihan and others were successful in doing and editor Gil Levine has allowed Lenihan to tell this story in his own words.

The current internecine warfare between the Canadian Auto Workers (CAW) and the rest of the affiliates of the Canadian Labour Congress stands in sharp contrast to the battles Lenihan and his contemporaries fought to establish public sector unionism as an integral part of a united house of labour.

Lofty goals of forming a national public sector union and uniting the two major factions within the Canadian labour movement must have seemed daunting just after the Second World war. But the time was right. Public sector workers were ready to embrace unionism and public sector employers were all too willing to sit down and negotiate with their unions. Civic employees were mobilized and energized by activists like Lenihan who were able to win substantial gains at the bargaining tables and in grievance settlements.

While civic employees' unions often have a long individual histories and many were members of the Trades and Labour Congress (TLC), it was not until the 1950 s that they made their presence felt. Before then, in Lenihan.'s words, "the civic employee unions within the TLC were always regarded by the industrial unions as second-class citizens." Activists such as Lenihan realized that civic employees were isolated in their unions with no common organizational bond to further their interests. They set out to correct that by trying to forge a national union for public employees.

In 1952 they convinced the TLC officers to issue a charter for a National Federation of Public Employees as a first step to forming a national union and in 1953 the 12,000 member organization was given the right to charter locals. In 1954 the National Union of Public Employees (NUPE) was formed. NUPE 